\title{
New distribution records for Sciomyzidae (Diptera) from the Pantanal, Brazil
}

\author{
Marcoandre Savaris ${ }^{1}$, Frederico Dutra Kirst ${ }^{2}$, Silvana Lampert ${ }^{1,3}$, Luciane Marinoni ${ }^{3}$ \\ 1 Departamento de Entomologia e Acarologia, Escola Superior de Agricultura "Luiz de Queiroz", Universidade de São Paulo, Av. Pádua Dias, \\ 11, Piracicaba, São Paulo, CEP 13418-900, Caixa Postal 9, Brazil. 2 Instituto de Ciências Biológicas, Departamento de Zoologia, Universidade \\ Federal de Minas Gerais, Belo Horizonte, Minas Gerais, CEP 31270-901, Caixa Postal 486, Brazil. 3 Setor de Ciências Biológicas, Departamento \\ de Zoologia, Programa de Pós-Graduação em Entomologia, Universidade Federal do Paraná, Curitiba, Paraná, CEP 81531-980, Caixa Postal 19020, \\ Brazil. \\ Corresponding author: Marcoandre Savaris, savaris@usp.br
}

\begin{abstract}
We document the geographical distribution of 6 species of Sciomyzidae from the Pantanal biome of Brazil. The species were collected in aquatic or semi-aquatic habitats from Mato Grosso and Mato Grosso do Sul. Sepedomerus bipuncticeps (Malloch, 1933) and Sepedonea canabravana Knutson \& Bredt, 1976 are new records from Mato Grosso and Sepedonea lindneri (Hendel, 1932), Sepedonea telson (Steyskal, 1951), Sepedonea veredae Freidberg, 1991, and Thecomyia limbata (Wiedemann, 1819) from Mato Grosso do Sul. Photographs of collection areas, the habitus of adults, and a distribution map of the species are provided.
\end{abstract}

\section{Keywords}

Biological control, first records, marsh-fly, Neotropical Region, snail-killing fly.

Academic editor: Kirstern Lica Follmann Haseyama | Received 22 October 2018 | Accepted 11 April 2019 | Published 31 May 2019

Citation: Savaris M, Kirst FD, Lampert S, Marinoni L (2019) New distribution records for Sciomyzidae (Diptera) from the Pantanal, Brazil. Check List 15 (3): 447-454. https://doi.org/10.15560/15.3.447

\section{Introduction}

The Sciomyzidae (Diptera) are a family of acalyptrate flies, commonly known as marsh or snail-killing flies and are considered "true malacophages" (Marinoni and Mathis 2006, Knutson and Vala 2011, Murphy 2014, Kirst et al. 2015). The family comprises more than 600 species in approximately 63 genera and occurs worldwide (Marinoni and Knutson 1992, Vala et al. 1999, 2012, 2013, Marinoni et al. 2003, Marinoni and Murphy 2016). The Neotropical Region has 103 species occurring in 25 genera (Berg and Knutson 1978, Knutson 1987, Marinoni and Mathis 2000, Marinoni and Murphy 2016). The most common species belong to the genera Sepedonea Steyskal, 1973 (13 species), Thecomyia Perty, 1833 (12 species), Protodictya Malloch, 1933 (8 species), Pherbellia Robineau-Desvoidy, 1830 (6 species), Sepedomerus Steyskal, 1973 (3 species), and Sepedon Latreille, 1804 (2 species) (Marinoni et al. 2003, Marinoni and Mathis 2006, Marinoni and Knutson 2010).

Most sciomyzid species with known biology have life cycles associated with mollusks (Barker et al. 2004, Knutson and Vala 2011); only 3 species are not associated (Vala et al. 2013). In the Neotropics, sciomyzids are predatory flies of aquatic or semi-aquatic gastropods (Berg and Knutson 1978, Barker et al. 2004, Marinoni 

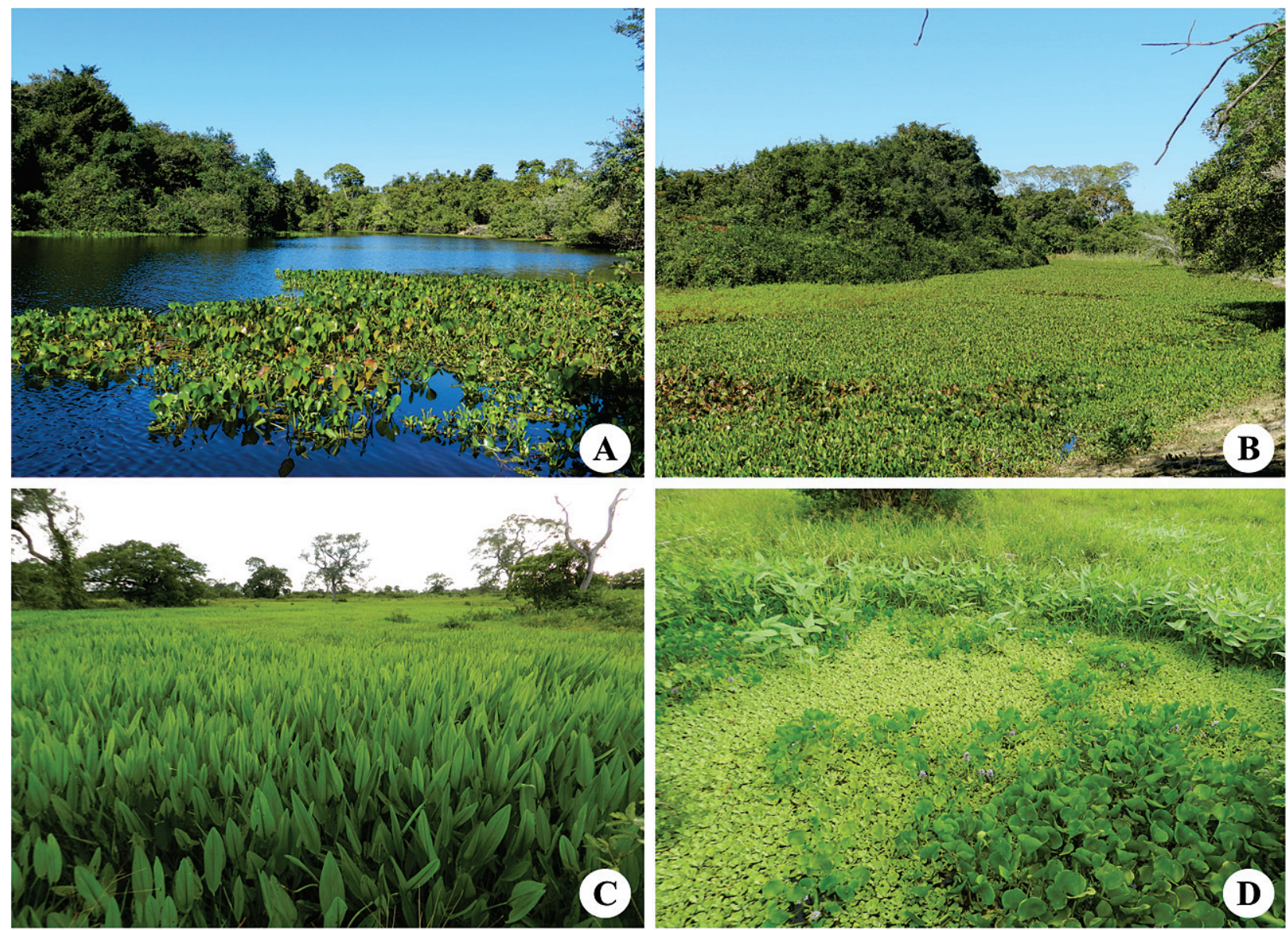

Figure 1. Environments of collection of Sciomyzidae. A, B. Clarinho River, Poconé, Mato Grosso. C. Temporary pond with aquatic plants, Rio Clarinho farm, Poconé, Mato Grosso. D. Temporary pond with aquatic plants in the middle of pasture, Anhumas farm, Bonito, Mato Grosso do Sul.

and Knutson 2010). Some species of aquatic snails are intermediate hosts of vectors that cause disease in humans, such as the fascioliasis and schistosomiasis, and snail-killing flies are potentially useful in applied ecology and as biocontrol agents of these gastropods (Gormally 1988, Maharaj et al. 1992, Barker et al. 2004, Marinoni and Knutson 2010, Kirst et al. 2015).

The Pantanal is the largest seasonally flooded area in South America, one of the largest wetland systems in the world (Nunes da Cunha and Junk 2015). The ecological basis for the diversity of species in this wetland system is the permanent habitats of the seasonally waterlogged and permanent dry areas (Junk et al. 2006). During periods of flood, a great number of lakes are formed that vary in size and depth according to the amount of rainfall. The resulting aquatic ecosystems, some of which are temporary, are rich in plant and animal diversity, including the family Sciomyzidae and their hosts. We report new records for 6 species of sciomyzids from Brazilian Pantanal region.

\section{Methods}

The Pantanal, the smallest Brazilian biome, is located in the states of Mato Grosso and Mato Grosso do Sul and occupies an area comprising just $1.7 \%$ of the national territory (IBGE 2004). This biome is characterized by a wide alluvial plain which is flooded during the rainy season by the rivers of the surrounding plateaus due to its low capacity of water flow (Alho et al. 1988, Barella et al. 2001, Alho 2003). In the Pantanal, the pluviometric regime presents 2 well-defined seasons, a rainy season from October to March and a dry season from April to September (Pereira et al. 2012). The climate in the states of the Mato Grosso (MT) and Mato Grosso do Sul (MS), according to the Koeppen climate classification system, is type Am (tropical monsoon climate; MT 47.2\% and MS 45.6\%), Aw (tropical savanna climate; MT 52.8\% and MS 36.6\%), and a smaller area with Cfa (humid subtropical climate; MS 11.2\%). The annual rainfall is between 1300 and $1900 \mathrm{~mm}$ (Alvares et al. 2013).

Specimens were collected from 2 sites, 1 each in Mato Grosso and Mato Grosso do Sul states. At the Rio Clarinho farm, municipality of Poconé, Mato Grosso (Figs 1A-C, 4), flies were sampled among the aquatic vegetation on the banks of the Clarinho River (Fig. 1A, B), with the help of a boat, and in temporary ponds with aquatic plants formed during the rainy season (Fig 1C). The specimens from Mato Grosso do Sul were collected at the Anhumas farm, municipality of Bonito (Figs 1D, 4 ), where the aquatic environments have the most-disturbed margins and surroundings; here, the vegetation is altered for pastures for beef cattle breeding (Fig 1D). 
Collections were made with an aerial net by sweeping vegetation, especially aquatic plants, where sciomyzids and their hosts usually occur. The insects were placed into plastic vials with $70 \%$ ethyl alcohol and taken to the Laboratório de Estudos em Diversidade de Insetos Neotropicais (TaxonLab) where they were prepared for identification. The specimens were identified with the aid of entomological keys and descriptions by Steyskal and Knutson (1975), Freidberg et al. (1991), Marinoni et al. (2003), and Marinoni and Mathis (2006).

Voucher specimens are deposited in the Entomological Collection Padre Jesus Santiago Moure, Department of Zoology, Universidade Federal do Paraná (DZUP). Specimens were databased in the Projeto Taxonline, Rede Paranaense de Coleções Biológicas (http://www. taxonline.bio.br).

Fieldwork was supported by the project Sisbiota "Diptera dos estados do Mato Grosso, Mato Grosso do Sul e Rondônia: diversidade, sistemática e limite distribucionais", aiming to understand the diversity and distribution of Diptera of the states of Mato Grosso, Mato Grosso do Sul and Rondônia, at the biomes Cerrado, Pantanal and Amazon. The collections were carried out under SISBIO authorization number 29705.

The distribution map was made using Quantum GIS 2.8. Longitude and latitude were obtained for each locality where specimens were collected using a Garmin $78 \mathrm{~S}$ GPS receiver.

The habitus of each species were photographed in dorsal and lateral views using a Leica DFC 500 mounted on a Leica MZ16 stereoscopic microscope; photographs were enhanced using Photoshop CS6 to correct the color and make minor corrections (e.g., remove debris).

\section{Results}

Sixteen specimens of marsh-flies belonging to the genera Sepedomerus, Sepedonea, and Thecomyia were collected and identified. For the first time, we present records of Sepedomerus bipuncticeps (Malloch, 1933) and Sepedonea canabravana Knutson \& Bredt, 1976 from Mato Grosso, and Sepedonea lindneri (Hendel, 1932), Sepe- donea telson (Steyskal, 1951), and Sepedonea veredae Freidberg, 1991 from Mato Grosso do Sul (Fig. 4; Table 1). Thecomyia limbata (Wiedemann, 1819) is for the first time recorded from municipality of Bonito, Mato Grosso do Sul, but it is not a new record for the state (see comments below).

\section{Sepedomerus bipuncticeps (Malloch, 1933)}

Figure 2A, B

New record. Brazil: Mato Grosso: Poconé, fazenda Rio Clarinho, $16^{\circ} 36^{\prime} 06.01^{\prime \prime} \mathrm{S}, 056^{\circ} 43^{\prime} 43.10^{\prime \prime} \mathrm{W}, 118 \mathrm{~m}, 16$ July 2012, sweep net, M. Savaris, 2 males (DZUP 342277, 342278).

Geographic distribution. Panama (Panama); Colombia (Valle del Cauca, Morga, Cali); Brazil (Acre, Goiás, Mato Grosso, Minas Gerais, Paraná, Rio Grande do Sul); Paraguay (Villarrica, Guaira); Uruguay (Montevideo, Colón); Argentina (D.F., Chaco, Buenos Aires, La Plata, Catamarca).

\section{Sepedonea canabravana Knutson \& Bredt, 1976 Figure 2C, D}

New record. Brazil: Mato Grosso: Poconé, fazenda Rio Clarinho, 16³6'06.01"S, 056 43'43.10"W, 118 m, 16 July 2012, sweep net, M. Savaris, 2 males (DZUP 342279, 342280).

Geographic distribution. Brazil (Goiás, Mato Grosso, Minas Gerais).

\section{Sepedonea lindneri (Hendel, 1932)}

Figure 2E, F

New record. Brazil: Mato Grosso do Sul: Bonito,

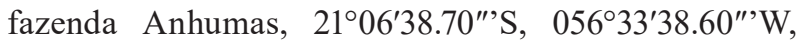
362 m, 12 Dec. 2012, sweep net, M. Savaris, S. Lampert, 1 male and 2 females (DZUP 342281, 342282, 342284).

Geographic distribution. Argentina (Buenos Aires, Catamarca, Chaco, Corrientes, Formosa, La Rioja, San José, Santa Fe, Tapikiole, Tucuman); Paraguay (La cordillera, San Bernardino, Trinidad); Brazil (Goiás, Mato Grosso do Sul; Rio Grande do Sul, Santa Catarina).

Table 1. List of species of Sciomyzidae collected from Pantanal Region. Where: $\mathrm{N}=$ Number of specimens collected. DZUP = Entomological Collection Padre Jesus Santiago Moure, Department of Zoology, Universidade Federal do Paraná.

\begin{tabular}{|c|c|c|c|c|c|c|c|c|}
\hline Taxon & $N$ & State & Municipality & Locality & Coordinates & Date & Collectors & Vouchers \\
\hline $\begin{array}{l}\text { Sepedomerus bipunticeps } \\
\text { (Malloch, 1933) }\end{array}$ & 2 & MT & Poconé & Faz. Rio Clarinho & $16^{\circ} 36^{\prime} 06^{\prime \prime} \mathrm{S}, 056^{\circ} 43^{\prime} 43^{\prime \prime} \mathrm{W}$ & $16 \mathrm{Jul} 2012$ & M. Savaris & DZUP \\
\hline $\begin{array}{l}\text { Sepedonea canabravana } \\
\text { Knutson \& Bredt, } 1976\end{array}$ & 2 & MT & Poconé & Faz. Rio Clarinho & $16^{\circ} 36^{\prime} 06^{\prime \prime} \mathrm{S}, 056^{\circ} 43^{\prime} 43^{\prime \prime} \mathrm{W}$ & $16 \mathrm{Jul} 2012$ & M. Savaris & DZUP \\
\hline $\begin{array}{l}\text { Sepedonea lindneri } \\
\text { (Hendel, 1932) }\end{array}$ & 3 & MS & Bonito & Faz. Anhumas & $21^{\circ} 06^{\prime} 38^{\prime \prime} \mathrm{S}, 056^{\circ} 33^{\prime} 38^{\prime \prime} \mathrm{W}$ & 12 Dec 2012 & M. Savaris, S. Lampert & DZUP \\
\hline $\begin{array}{l}\text { Sepedonea telson } \\
\text { (Steyskal, 1951) }\end{array}$ & 3 & MS & Bonito & Faz. Anhumas & $21^{\circ} 06^{\prime} 38^{\prime \prime S}, 056^{\circ} 33^{\prime} 38^{\prime \prime} \mathrm{W}$ & 12 Dec 2012 & M. Savaris, S. Lampert & DZUP \\
\hline $\begin{array}{l}\text { Sepedonea veredae } \\
\text { Freidberg, } 1991\end{array}$ & 2 & MS & Bonito & Faz. Anhumas & $21^{\circ} 06^{\prime} 38^{\prime \prime} \mathrm{S}, 056^{\circ} 33^{\prime} 38^{\prime \prime} \mathrm{W}$ & 12 Dec 2012 & M. Savaris, S. Lampert & DZUP \\
\hline $\begin{array}{l}\text { Thecomyia limbata } \\
\text { (Wiedemann, 1819) }\end{array}$ & 4 & MS & Bonito & Faz. Anhumas & $21^{\circ} 06^{\prime} 38^{\prime \prime} \mathrm{S}, 056^{\circ} 33^{\prime} 38^{\prime \prime} \mathrm{W}$ & 12 Dec 2012 & M. Savaris, S. Lampert & DZUP \\
\hline
\end{tabular}



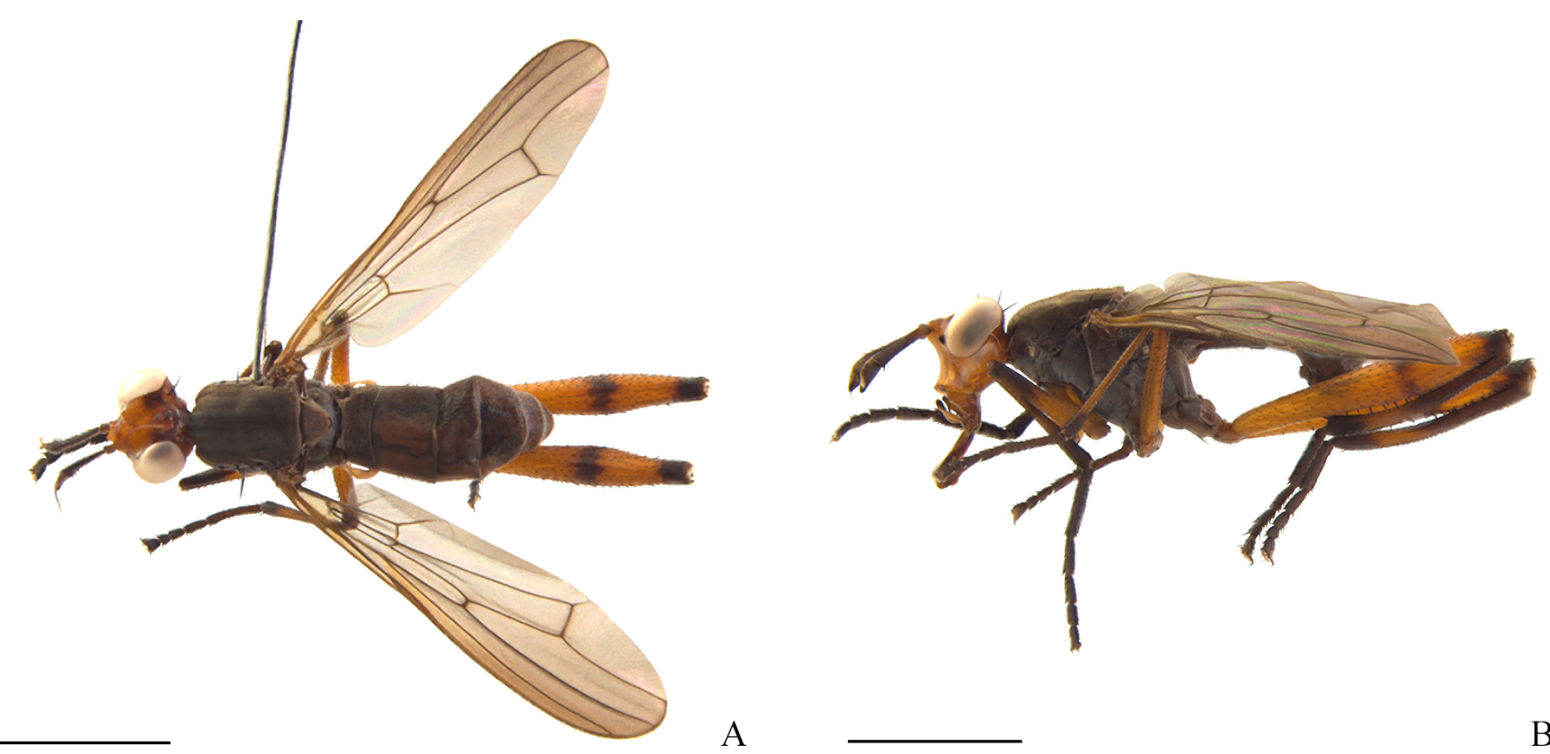

A

B
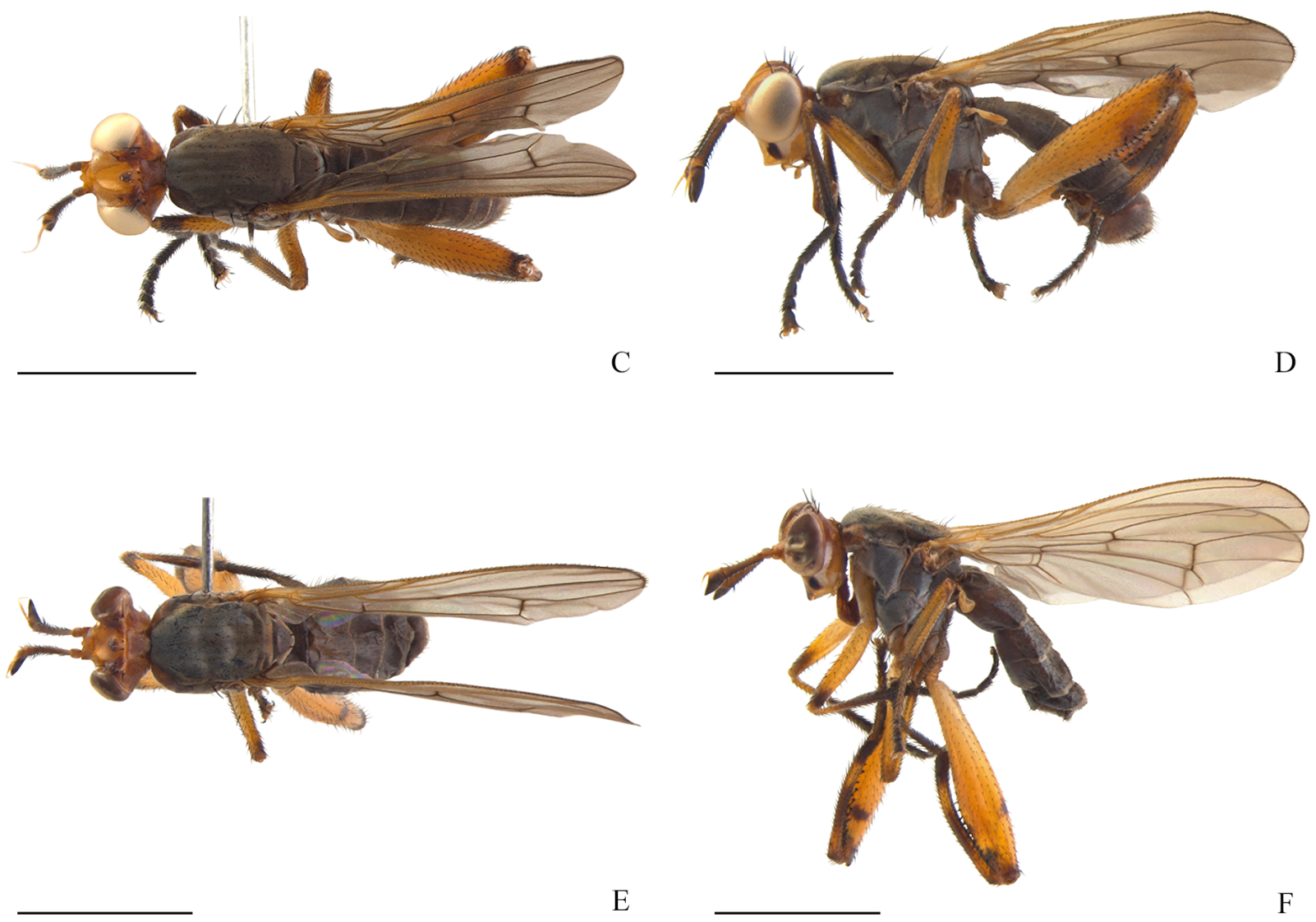

Figure 2. Habitus of the species of Sciomyzidae from Pantanal region. A, B. Sepedomerus bipuncticeps (Malloch, 1933). A. Dorsal view. B. Lateral view. C, D. Sepedonea canabravana Knutson \& Bredt, 1976. C. Dorsal view. D. Lateral view. E, F. Sepedonea lindneri (Hendel, 1932). E. Dorsal view. F. Lateral view. Scale bars $=2 \mathrm{~mm}$.

\section{Sepedonea telson (Steyskal, 1951)}

Figure 3A, B

New record. Brazil: Mato Grosso do Sul: Bonito, fazenda Anhumas, $21^{\circ} 06^{\prime} 38.70^{\prime \prime} \mathrm{S}, 056^{\circ} 33^{\prime} 38.60^{\prime \prime} \mathrm{W}, 362 \mathrm{~m}, 12$ Dec. 2012, sweep net, M. Savaris, S. Lampert, 1 male and 2 females (DZUP 342285, 342286, 342287).
Geographic distribution. Brazil (Mato Grosso do Sul, Minas Gerais, São Paulo, Paraná, Santa Catarina).

\section{Sepedonea veredae Freidberg, 1991}

Figure 3C, D

New record. Brazil: Mato Grosso do Sul: Bonito, fazenda 


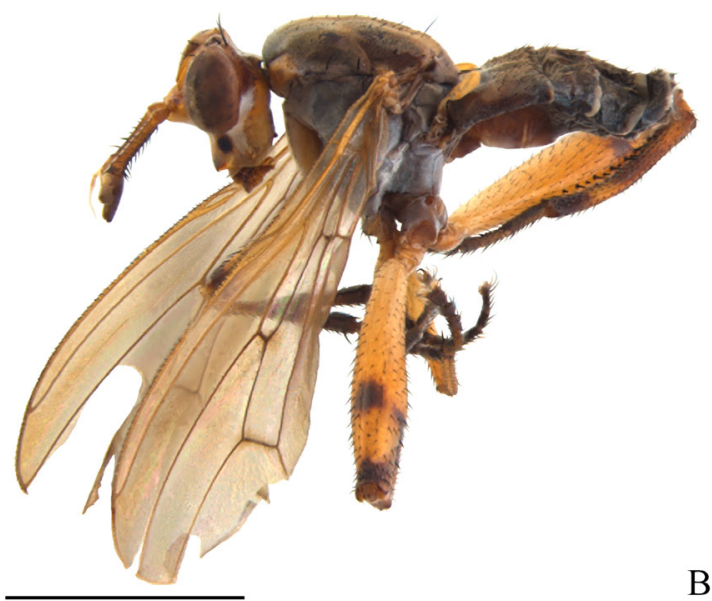

B
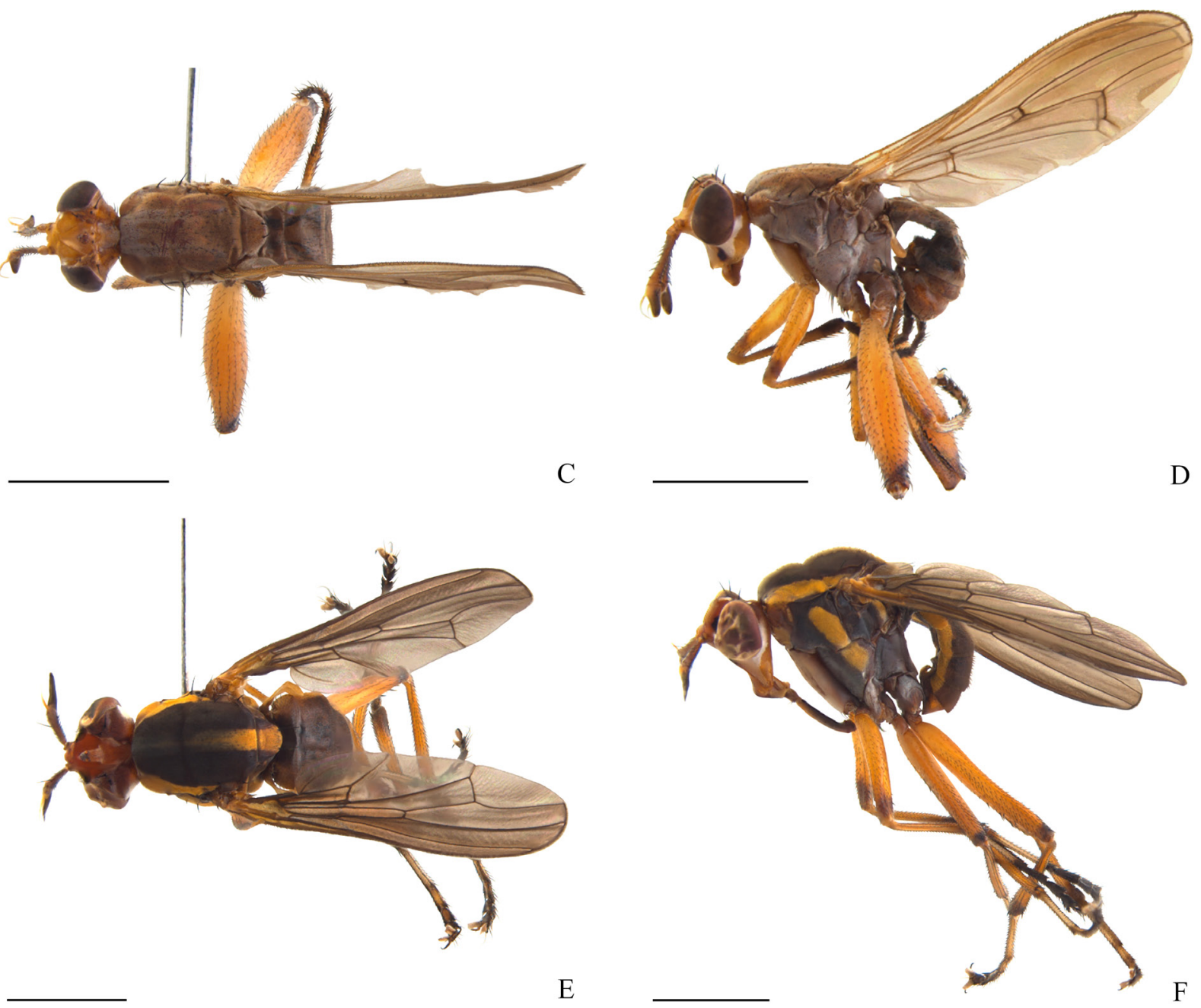

Figure 3. Habitus of the species of Sciomyzidae from Pantanal region. A, B. Sepedonea telson (Steyskal, 1951). A. Dorsal view. B. Lateral view. C, D. Sepedonea veredae Freidberg, 1991. C. Dorsal view. D. Lateral view. E, F. Thecomyia limbata (Wiedemann, 1819). E. Dorsal view. F. Lateral view. Scale bars $=2 \mathrm{~mm}$.

Anhumas, $21^{\circ} 06^{\prime} 38.70^{\prime \prime} \mathrm{S}, 056^{\circ} 33^{\prime} 38.60^{\prime \prime} \mathrm{W}, 362 \mathrm{~m}, 12$ Dec. 2012, sweep net, M. Savaris, S. Lampert, 1 male and 1 female (DZUP 342292, 342294).

Geographic distribution. Brazil (Bahia, Espírito Santo, Mato Grosso, Mato Grosso do Sul, Pernambuco, Sergipe).

\section{Thecomyia limbata (Wiedemann, 1819)}

Figure 3E, F

New Record. Brazil: Mato Grosso do Sul: Bonito, fazenda Anhumas, $21^{\circ} 06^{\prime} 38.70^{\prime \prime} \mathrm{S}, 056^{\circ} 33^{\prime} 38.60^{\prime \prime} \mathrm{W}, 362 \mathrm{~m}, 12$ Dec. 2012, sweep net, M. Savaris, S. Lampert, 2 males and 2 females (DZUP 342288, 342289, 342290, 342291). 


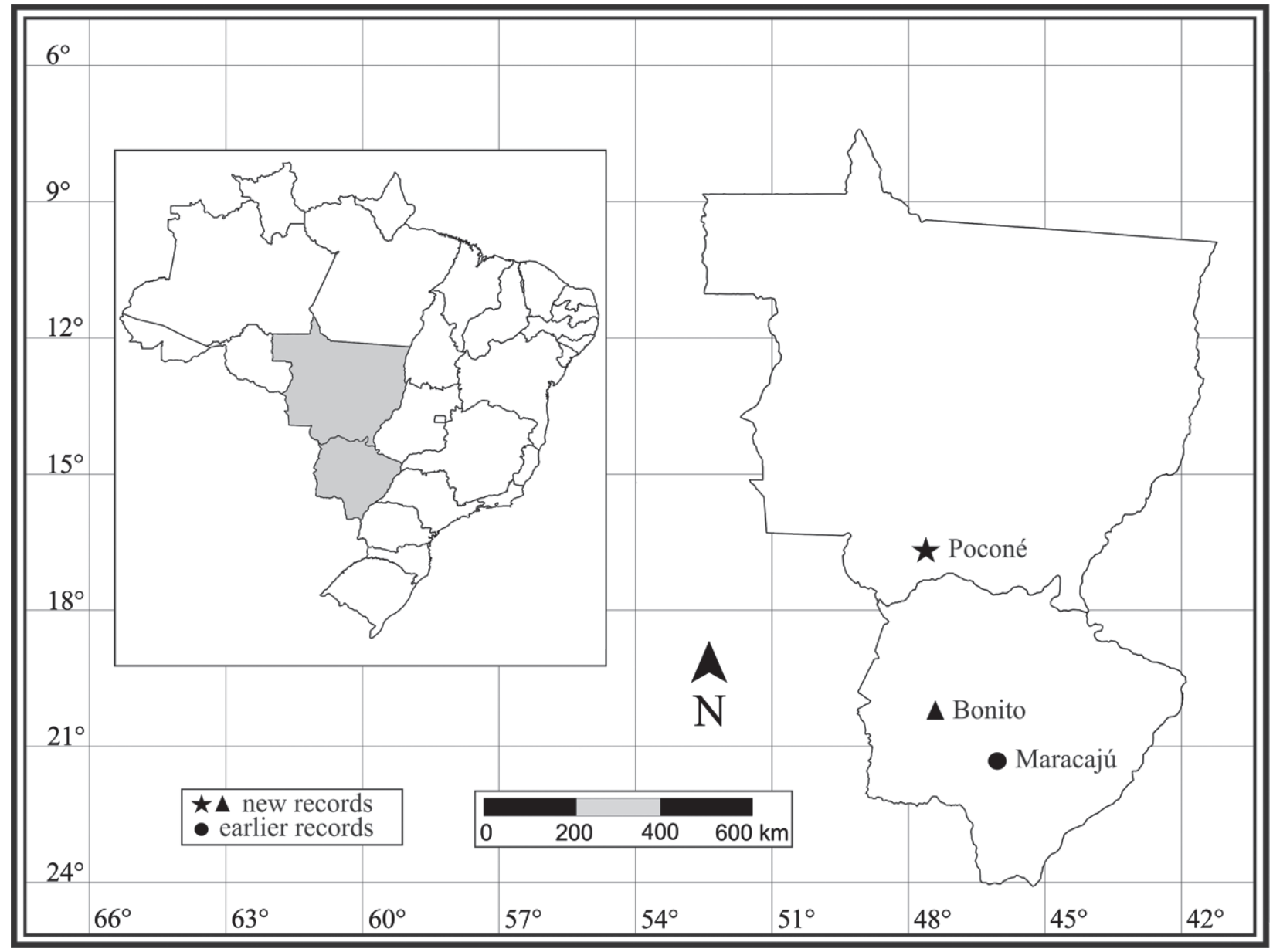

Figure 4. New records $(\star \mathbf{\Delta})$ and earlier record $(\bullet)$ of the species of Sciomyzidae from Pantanal region. ( $\star$ ) Poconé, Mato Grosso (Sepedomerus bipuncticeps (Malloch, 1933) and Sepedonea canabravana Knutson \& Bredt, 1976). (ム) Bonito, Mato Grosso do Sul (Sepedonea lindneri (Hendel, 1932), Sepedonea telson (Steyskal, 1951), Sepedonea veredae Freidberg, 1991, and Thecomyia limbata (Wiedemann, 1819)). (•) Maracajú, Mato Grosso do Sul (Thecomyia limbata (Wiedemann, 1819)).

Geographic distribution. Brazil (Rio Grande do Norte; Distrito Federal; Mato Grosso do Sul; Rio de Janeiro; São Paulo; Paraná), Ecuador, Panama, Paraguay, Venezuela.

In 1937, when T. limbata was collected in Maracaju the states of Mato Grosso and Mato Grosso do Sul were a single federal unit named Mato Grosso. Nowadays the municipality of Maracaju is in Mato Grosso do Sul and T. limbata is thus recorded from that state.

Identification. The genus Sepedomerus is characterized by the elongated hind femur, which is almost twice as long as the abdomen (Fig. 2A, B). Sepedomerus bipuncticeps is differentiated from its congeners by the dull frons, which lacks sharp ridges, and by the upper portion of pleura, which is pale and pruinose.

The genus Sepedonea is characterized by the darkbrown spot at the ventral corner of its face (Figs 2D, F, $3 \mathrm{~B}, \mathrm{D})$ and by the fore femur which has at least 1 outstanding dorsal seta. Sepedonea species can be differentiated using the key by Freidberg et al. (1991) and observing structures of the terminalia. Sepedonea canabravana differs from $S$. lindneri and S. telson in having the hind femur without a dark dorsal preapical mark (Fig 2C). Sepedonea lindneri differs from S. telson in having a rounded dorsal mark on hind femur (Fig. 2E). Sepedonea telson differs from $S$. lindneri in having an elongate dorsal mark on hind femur (Fig. 3A, B). Sepedonea veredae differs from $S$. canabravana, S. lindneri, and $S$. telson in having the hind femur without preapical marks and the mesonotum usually yellowish (Fig 3C).

The genus Thecomyia (Fig. 3E, F) is easily recognized within the family. It is distinguished from other sciomyzid genera by the narrow, conical, and ventral development of the head, which forms a rostrum within which the entire proboscis can be retracted. There is also a complete reduction of the palpi and most body setae are strongly reduced. Thecomyia limbata was identified using the key by Marinoni et al. (2003), which primarily uses the structures of the terminalia.

\section{Discussion}

The genera Thecomyia, Sepedonea, and Sepedomerus contain Neotropical species that are well known mainly from southern Brazil. Of the 6 species collected, the natural history of 4 of them is known. Thecomyia limbata, Sepedonea canabravana, S. lindneri, and $S$. telson all have predaceous larvae of freshwater, 
non-operculate snails (Neff and Berg 1966, Abercrombie and Berg 1975, Bredt and Mello 1978, Marinoni and Mathis 2000); the adults might be active nectar feeders on flowers (Knutson and Vala 2011). The species of these genera are almost always collected in ponds and marshes where aquatic snails occur. In southern Brazil, they have been collected mainly during the summer and in the warmer period of the day (LM, pers. obs.). In Pantanal, specimens of these species were collected during July and December.

Sepedonea canabravana has been associated with freshwater snails and in Pantanal was collected in July during the dry season, as well as $S$. bipuncticeps. The other 4 species, S. lindneri, S. telson, S. veredae and $T$. limbata were collected in December during the rainy season. A more exhaustive survey is needed to understand the seasonal distribution of these species and also their host.

The geographical distribution of the species, in conjunction with knowledge of their biology, is very important in reconstructing the history of the evolutionary units as well as the history of the areas. In the biogeographical analyses of Sepedonea and Thecomyia species by Pires et al. (2008) and Pires and Marinoni (2011) the importance of sciomyzids in studies of coevolution and biogeography was emphasized because of their close relationship with mollusks and their reduced flight capacity.

\section{Acknowledgements}

We thank the Sisbiota project "Diptera dos estados do Mato Grosso, Mato Grosso do Sul e Rondônia: diversidade, sistemática e limite distribucionais" and all members involved. We gratefully acknowledge the assistance and support from CNPq, Conselho Nacional de Desenvolvimento Científico e Tecnológico, Brazil (Process numbers 563256/2010-9, 142105/2012-0, and 200277/2015-4) and FAPESP, Fundação de Amparo à Pesquisa do estado de São Paulo (Process number 2010/52314-0). We thank Dr Wayne Mathis for revising the manuscript. We thank the Programa de Pós-Graduação em Entomologia USP/ESALQ. We also acknowledge the 2 anonymous reviewers and the academic editor for improving the manuscript.

\section{Authors' Contributions}

MS and SL collected the specimens in the field; all authors wrote the text; FDK and LM examined the specimens and verified identification; MS and SL prepared the map and figures; FDK and MS took the photographs.

\section{References}

Abercrombie J, Berg CO (1975) Natural history of Thecomya limbata (Diptera: Sciomyzidae) from Brazil. Proceedings of the Entomological Society of Washington 77: 355-368.

Alho CJR (2003) Conservação da Biodiversidade da Bacia do Alto
Paraguai. Editora UNIDERP, Campo Grande, 420 pp.

Alho CJR, Lacher JTE, Gonçalves HC (1988) Environmental degradation in the Pantanal ecosystem of Brazil. BioScience 38: 164-171. https://doi.org/10.2307/1310449

Alvares CA, Stape JL, Sentelhas PC, Gonçalves JLM, Sparovek G (2013) Köppen's climate classification map for Brazil. Meteorologische Zeitschrift 22: 711-728. https://doi.org/10.1127/09412948/2013/0507

Barella W, Petrere JM, Smith WS, Montag LFA (2001) As relações entre as matas ciliares, os rios e os peixes. In: Rodrigues RR, Leitão Filho HF (Eds) Matas Ciliares: Conservação e Recuperação. EDUSP, São Paulo, 187-207.

Barker GM, Knutson L, Vala JC, Coupland JB, Barnes JK (2004) Overview of the biology of marsh flies (Diptera: Sciomyzidae), with special reference to predators and parasitoids of terrestrial gastropods. In: Barker GM (Ed.) Natural Enemies of Terrestrial Molluscs. CABI Publishing, Wallingford, 159-225. https://doi. org/10.1079/9780851993195.0159

Berg CO, Knutson LV (1978) Biology and systematics of the Sciomyzidae. Annual Review of Entomology 23: 239-258. https://doi. org/10.1146/annurev.en.23.010178.001323

Bredt A, Mello DA (1978) Nota sobre o ciclo biológico de duas espécies de dípteros da família Sciomyzidae. Revista Brasileira de Biologia 38: 767-770.

Freidberg A, Knutson L, Abercrombie J (1991) A revision of Sepedo$n e a$, a Neotropical genus of snail-killing flies (Diptera: Sciomyzidae). Smithsonian Contributions to Zoology 506: 1-48. https:// doi.org/10.5479/si.00810282.506

Gormally MJ (1988) Studies on the oviposition and longevity of Ilione albiseta (Dipt.: Sciomyzidae) potential biological control agent of liver fluke. Entomophaga 33: 387-395. https://doi.org/10.1007/ BF02373174

IBGE (2004) Instituto Brasileiro de Geografia e Estatística. Mapa de biomas e vegetação. https://ww2.ibge.gov.br/home/presidencia/ noticias/21052004biomashtml.shtm. Accessed on: 2018-5-26.

Junk WJ, Bayley PB, Sparks RE (1989) The flood pulse concept in river-floodplain systems. In: Dodge DP (Ed.) Proceedings of the International Large River Symposium. Canadian Special Publication of Fisheries and Aquatic Sciences 106: 110-127.

Junk WJ, Nunes Da Cunha C, Wantzen KM, Petermann P, Strüssmann C, Marques MI, Adis J (2006) Biodiversity and its conservation in the Pantanal of Mato Grosso, Brazil. Aquatic Sciences 68: 278-309. https://doi.org/10.1007/s00027-006-0851-4

Kirst FD, Marinoni L, Krüger RF (2015) New distribution records for Sciomyzidae species (Insecta, Diptera) from Rio Grande do Sul, Brazil. Check List 11 (1): 1552. https://doi.org/10.15560/11.1.1552

Knutson LV (1987) Sciomyzidae. In: McAlpine JF (Ed.) Manual of Neartic Diptera 2. Biosystematics Research Centre, Ottawa, 927-940.

Knutson LV, Vala JC (2011) Biology of Snail-killing Sciomyzidae Flies. Cambridge University Press, New York, 526 pp.

Maharaj R, Appleton CC, Miller RM (1992) Snail predation by larvae of Sepedon scapularis Adams (Diptera: Sciomyzidae), a potential biocontrol agent of snail intermediate hosts of schistosomiasis in South Africa. Medical and Veterinary Entomology 6: 183-187. https://doi.org/10.1111/j.1365-2915.1992.tb00604.x

Marinoni L, Knutson LV (1992) Revisão do gênero Neotropical Protodictya Malloch, 1933 (Diptera, Sciomyzidae). Revista Brasileira de Entomologia 36: 25-45.

Marinoni L, Knutson LV (2010) Sciomyzidae. In: Brown BV, Borkent A, Cumming JM, Wood DM, Woodley NE, Zumbado MA (Eds) Manual of Central American Diptera, Vol. 2. NRC Research Press, Ottawa, 1017-1024.

Marinoni L, Mathis WN (2000) A cladistic analysis of Sciomyzidae Fallén (Diptera). Proceedings of Biological Society of Washington 113: 162-209.

Marinoni L, Mathis WN (2006) A cladistic analysis of the Neotropical genus Sepedonea Steyskal (Diptera: Sciomyzidae). Zootaxa 
1236: 37-52. https://doi.org/10.15468/uvjwvk

Marinoni L, Murphy WL (2016) Family Sciomyzidae. In: Wolff M, Nihei SS, Carvalho CJB (Eds) Catalogue of Diptera of Colombia. Zootaxa 4122 (1): 642-647. http://doi.org/10.11646/ zootaxa.4122.1.53

Marinoni L, Steyskal GC, Knutson LV (2003) Revision and cladistic analysis of the Neotropical genus Thecomyia Perty (Diptera: Sciomyzidae). Zootaxa 191: 1-36. http://doi.org/10.11646/ zootaxa.191.1.1

Mello DA, Bredt A (1978) Distribuição geográfica de Sciomyzidae (Diptera: Insecta) no Distrito Federal e em algumas regiões de outros estados do Brasil. Ciência e Cultura 30 (2): 212-215.

Murphy WL (2014) Dictya behrmani, a new species of snail-killing fly (Diptera: Sciomyzidae) from Indiana. Proceedings of the Entomological Society of Washington 11 (1): 91-97. https://doi. org/10.4289/0013-8797.116.1.91

Neff SE, Berg CO (1966) Biology and immature stages of malacophagous Diptera of the genus Sepedon (Sciomyzidae). Virginia Agricultural Experiment Station Bulletin 566: 1-113.

Nunes da Cunha C, Junk WJ (2015) A Classificação dos Macrohabitats do Pantanal Matogrossense. In: Nunes da Cunha C, Fernandez MTP, Junk WJ (Eds) Classificação e Delineamento das Áreas Úmidas Brasileiras e de seus Macrohabitats. EdUFMT, Cuiabá, $77-122$.
Pereira G, Chávez ES, Silva MES (2012) O estudo das unidades de paisagem do bioma Pantanal. Revista Ambiente \& Água 7 (1) 89-103. http://doi.org/10.4136/ambi-agua.826

Pires AC, Marinoni L (2011) Distributional patterns of the Neotropical genus Thecomyia Perty (Diptera, Sciomyzidae) and phylogenetic support. Revista Brasileira de Entomologia 55: 6-14. http:// doi.org/10.1590/S0085-56262011000100002

Pires AC, Marinoni L, Carvalho CJB (2008) Track analysis of the Neotropical genus Sepedonea Steyskal (Diptera: Sciomyzidae): a proposal based on the phylogenetic analysis of its species. Zootaxa 1716: 21-34.

Steyskal GC, Knutson LV (1975) Key to the genera of Sciomyzidae (Diptera) from the Americas south of the United States, with descriptions of two new genera. Proceedings of the Entomological Society of Washington 77: 274-277.

Vala JC, Knutson LV, Gasc C (1999) Stereoscan studies with descriptions of new characters of the egg and larval instars of Salticella fasciata (Meigen) (Diptera: Sciomyzidae). Journal of Zoology 247: 531-536. https://doi.org/10.1111/j.1469-7998.1999.tb01014.x

Vala JC, Murphy WL, Knutson LV, Rozkošný R (2012) A cornucopia for Sciomyzidae (Diptera). Studia Dipterologica 19 (1-2): 67-137.

Vala JC, Murphy WL, Knutson LV, Rozkošný R (2013) Corrigenda for the publication "A cornucopia for Sciomyzidae (Diptera)". Studia Dipterologica 20 (2): 183-188. 